\title{
Letter from the Editor-in-Chief: FDI spillovers and linkages
}

\section{Lorraine Eden}

Journal of International Business Studies (2009) 40, 1065-1069.

doi: $10.1057 / j i b s .2009 .46$

\section{INTRODUCTION}

This issue of JIBS begins with a Letter from the Editors on interdisciplinary research in international business (IB). The Letter, written by Cheng, Henisz, Roth and Swaminathan, discusses the role of interdisciplinary research in the field of $\mathrm{IB}$, the rewards and difficulties of doing interdisciplinary research, and ends by issuing "a call to arms to the field at a moment of threat and potential."

The issue also contains eight articles and one research note. Four of the nine manuscripts were originally submitted to the former editorial team and the remainder to the new team; all of the manuscripts were accepted under my watch. Although all of the manuscripts add important contributions to our knowledge of IB studies, I would like to highlight the contributions of the first five articles to our understanding of foreign direct investment (FDI) spillovers.

\section{FDI SPILLOVERS AND LINKAGES}

Although most IB scholars have a rudimentary knowledge of spillovers and linkages, the literature is highly technical and specialized, and tends to be dominated by economists. A short introduction to this area, for the broader JIBS readership, may therefore be useful background reading.

When analyzing the impact of FDI on host countries, IB scholars teach their students that FDI brings a package of capital, technology and management skills to the host country. The classic article is MacDougall (1960), who analyzed the impacts of inward FDI on host country welfare. He reviewed many possible effects including the indirect impact of technology spillovers.

Spillovers (or externalities) are impacts on third parties not directly involved in an economic transaction, that is, when a transaction between A and B affects C (Pigou, 1920). In such cases, the parties to the transaction (firms, consumers or factor owners) either do not bear all of the costs or do not reap all of the benefits from the transaction. Positive (social benefits exceed private benefits) or negative (social costs exceed private costs) spillovers are created. The existence of spillovers, however, is not always a matter for concern. Externalities can be divided into two groups, pecuniary and non-pecuniary; only non-pecuniary spillovers cause misallocation of resources (Scitovsky, 1954).

Pecuniary (or vertical) spillovers are impacts on third parties caused by changes in relative prices of goods, factors or assets in response to an economic transaction. Dunning and Lundan 
(2008: 551) define pecuniary spillovers as arising from buyer-supplier linkages involving the multinational enterprise (MNE) that affect, whether intended or unintended, "the amount and/or conditions of supply of, or the demand for, other goods and services by another firm, or by consumers." For example, when FDI in the oil and gas industry increases the demand for engineers, this drives up labor costs for all firms employing engineers, and a negative pecuniary externality is created. Pecuniary spillovers therefore reflect the workings of the market through relative price changes.

Non-pecuniary (or technological) spillovers, on the other hand, are real resource impacts on third parties that occur when the activities of one firm affect the technology or productivity of another firm in ways that cannot be captured by the first firm. Although non-pecuniary is a broader concept than technological, I follow common practice and use the term "technological spillovers" in the remainder of this editorial. Technological spillovers are informal, involuntary, non-market transfers (Eden, Levitas, \& Martinez, 1997). Well-known examples of negative spillovers are pollution and overconsumption of common property resources. Examples of positive spillovers include informal knowledge transfers that occur through labor market exchanges and demonstration effects as local firms copy the MNE's product or process technologies. The entry of an MNE into an industry can also generate competitive pressures on local firms whereby the "fresh winds of competition" force local firms to use existing technologies more efficiently or upgrade in order to remain competitive, creating an additional source of technological spillovers. The quest by economists to measure technological spillovers from FDI has been so attractive, according to Dunning and Lundan (2008: 592), because "they represent the proverbial 'free lunch' - something useful that is received without full compensation having to be paid."

Although vertical linkages generate primarily pecuniary spillovers, they often also create technological spillovers as a byproduct. For example, buyer-supplier linkages involving an MNE can facilitate learning-by-doing by local firms, raising their productivity. MNE training of host country employees provides a more highly skilled and productive labor pool and a potential source of new start-up firms, creating external benefits for upstream and downstream firms. All of these activities generate informal, unintended, non-market transfers. Because vertical linkages can create both pecuniary and technological spillovers, they are often difficult to disentangle. From the perspective of FDI, the key to technological spillovers is that there are residual impacts from FDI that accrue to local firms and organizations for which the foreign entrants are uncompensated. These residual impacts are expected to raise the overall level of productivity at the industry and possibly the national level, and thus increase national welfare in the host country (MacDougall, 1960).

There is at least one important difference between pecuniary and technological spillovers (Holcombe \& Sobel, 2001). Pecuniary spillovers reflect the workings of the market system. As there are both winners and losers from changes in market prices, the gains and losses cancel one another, and public policy intervention is not required to correct the externality. On the other hand, technological spillovers reflect differences between social and private impacts that are not reflected in market prices and can therefore generate inefficiencies (too much or too little being produced). As a result, public policy intervention may be needed for market prices to reflect social costs and benefits.

There is a second difference between the two types of spillovers that comes into play with MNEs and FDI. The argument that pecuniary spillovers can be ignored because the winners and losers cancel one another assumes winners and losers have the same weight in national welfare calculations. However, where one group consists of foreign owners, the welfare impact of pecuniary spillovers on income earned by residents (measured by Gross National Product (GNP)) differs from the impact on income earned within the borders of a country (measured by Gross Domestic Product (GDP)). In this case, the host government might care about the welfare impacts of pecuniary spillovers as they can affect GNP, even if GDP is unchanged (MacDougall, 1960). Thus, it is rational for host country governments to encourage backward and forward linkages, even if the impacts are wholly pecuniary, because such linkages can add to national welfare as measured by GNP.

As vertical linkages can generate both pecuniary and technological spillovers, it is often difficult to disentangle linkages from spillovers, and scholars may confuse or equate the two. Moreover, because of the difficulty of sorting out pecuniary from technological spillovers, researchers have tended to separate spillovers into categories that are more easily captured empirically. 
One well-known categorization of spillovers is intraindustry, interindustry and agglomeration/network (Harris \& Robinson, 2004). Intraindustry spillovers from FDI are technological spillovers that affect firms (competitors) in the same industry. These spillovers arise from demonstration effects (e.g., imitating FDI products and processes), competition effects (e.g., local firm responses to the "fresh winds of competition"), and labor market impacts (e.g., FDI creates a more highly trained labor pool).

Interindustry spillovers from FDI are pecuniary and technological spillovers generated from vertical linkages between firms in different industries. In practice, scholars estimating interindustry spillovers tend to focus on the technological spillovers generated by buyer-supplier linkages, and pecuniary spillovers are either ignored or included in the productivity estimates.

Lastly, agglomeration spillovers refer to the pecuniary and technological spillovers that arise from clusters and networks; these impacts can be intraindustry or interindustry (Dunning \& Lundan, 2008). Again, the empirical focus has been on technological spillovers. A typical example of agglomeration spillovers is knowledge spillovers generated by geographically clustered high-tech firms in Silicon Valley (Almeida \& Kogut, 1999).

\section{FDI SPILLOVERS IN JIBS 40.7}

This issue of JIBS contains four articles investigating the proverbial "free lunch" generated by FDI spillovers to host countries. The first article, "When and where does foreign direct investment generate positive spillovers? A meta-analysis," by Meyer and Sinani, conducts a meta-analysis of 66 econometric studies estimating the impact of FDI on host firm productivity (i.e., technological spillovers). The authors argue that the effects depend on the host country firms' (i) awareness of the potential impacts of FDI entry; (ii) motivation to change strategy in response to entry; and (iii) capabilities for absorbing the potential spillovers from FDI entry. They also argue that the "awareness-motivation-capability" (AMC) framework (Chen, Su, \& Tsai, 2007) works differently for firms in developing versus developed economies. If the entrant is a developed market firm entering another developed economy, the authors argue, the between-country technological gap should be small. Since the two groups of firms are similar, host country firms' awareness, motivation and capability should be high. As a result, through competitive interactive behaviors, the host firms should capture most of the potential spillovers. When a developed market firm enters a developing economy, the betweencountry technological gap should be large, so potential spillovers are high. However, since the two groups of firms are different, the host country firms' awareness, motivation and capability to absorb the spillovers are low, hindering absorption of the spillovers. In effect, Meyer and Sinani distinguish between potential and actual FDI spillovers. Foreign entrants offer potential spillovers, but the size of actual spillovers is constrained by the awareness, motivation and capability of host country firms, which indirectly depend on the host country's level of institutions and economic development.

The AMC framework has direct applicability to the next two articles as well. "Do all firms benefit equally from downstream FDI? The moderating effect of local suppliers' capabilities on productivity gains," by Blalock and Simon, argues that host country suppliers do not all benefit equally from new technologies introduced by downstream FDI entrants. Whether and how much they benefit depends on the local firms' capabilities in production, complementary resources, and absorptive capacity. The article examines buyer-supplier linkages, but focuses on the technological spillovers from downstream MNEs to upstream domestic suppliers. The authors link host country firms' capabilities to motivation, arguing that weaker production capabilities provide stronger motivation to adopt new technologies provided by the downstream foreign firms. On the other hand, greater absorptive capacity and complementary capabilities increase local firms' ability to benefit from FDI and provide stronger motivation to adopt new technologies. Panel data from Indonesian manufacturing establishments between 1988 and 1996 provide support for their arguments. Thus, as in Meyer and Sinani, local firms' motivations and capabilities affect their productivity gains from FDI.

Liu, Wang and Wei in "Do local manufacturing firms benefit from transactional linkages with multinational enterprises in China?" examine technological spillovers, both intraindustry and interindustry, from FDI entries into China between 1998 and 2001. The authors also test the geographic spread of these spillovers by examining both within-region and between-region changes in firms' productivity. A key difference in this paper is the intent to measure not only the impacts on domestic Chinese firms, but also the impacts of FDI on other foreign entrants. The authors find that a firm's absorptive capacity is the key determinant 
of productivity impacts; the greater the absorptive capability, the larger the productivity gains. Stateowned firms appear to outperform non-stateowned firms, possibly due to their larger size and state support.

"Domestic plant productivity and incremental spillovers from foreign direct investment" by Altomonte and Pennings adds another piece to our understanding of the spillovers puzzle. Presumably, the first foreign entrant offers the largest potential spillover gains to host country firms. What happens as more and more entrants arrive do the spillovers taper off? Using data on FDI entries into the manufacturing and service industries in Romania over 1990-2001, the authors find that the marginal spillover benefits decline with more entries - the Law of Diminishing Marginal Returns also applies to spillovers! Moreover, the domestic industry becomes more crowded and competition more intense as the number of foreign entrants rises. When diminishing marginal productivity returns are combined with increased crowding out of domestic firms due to competition from foreign entries, the average productivity gains of domestic firms may fall and even become negative. The authors conclude that their analysis may help to explain why so many FDI spillover studies find no average productivity gains.

The fifth article is indirectly related to spillovers and linkages. "Product and geographic scope changes of multinational enterprises in response to international competition" by Hutzschenreuter and Gröne discusses the impact of foreign entries, either through imports or FDI, on domestic firm strategies. Using the AMC framework, the authors argue that if domestic firms perceive foreign entries as a competitive attack, the incumbents are likely to choose an indirect strategic response and increase their product and geographic scope, with ex ante scope levels negatively moderating these relationships. (The response to import penetration, on the other hand, is to reduce scope.) The arguments are supported by an analysis of scope changes for 407 US and 95 German firms over the 1987-2003 period. This paper provides additional support for the AMC framework as a useful theoretical lens for understanding technological spillovers from FDI entry.

\section{REFERENCES}

Almeida, P., \& Kogut, B. 1999. Localization of knowledge and the mobility of engineers in regional networks. Management Science, 45(7): 905-917.

\section{OTHER HIGHLIGHTS OF JIBS 40.7}

"Is there a better commitment mechanism than cross-listings for emerging-economy firms? Evidence from Mexico" by Siegel argues that emerging market firms have difficulty acquiring foreign finance and technology because weak rule of law at home makes it difficult for firms to pre-commit to not expropriating an outside investor. The author compares international strategic alliances, political connections, and cross-listing shares on a developed market stock exchange as alternative "reputational bonding" mechanisms for emerging market firms. Looking at Mexican firms' responses to the peso crisis of 1994-1995, Siegel finds that international strategic alliances were the best method for promoting better corporate governance.

The last three pieces in JIBS 40.7 are regional in their focus. "Local, regional or global? Quantifying MNC geographic scope" by Asmussen creates a multidimensional index to measure regional and global orientation of firms. The author finds that large multinationals follow home-oriented paths of internationalization, and that as a result, the regional effect observed in previous studies may reflect the MNE's strong home country bias. "Expanding RTAs, trade flows, and the multinational enterprise" by Fratianni and Oh uses a gravity equation approach to test the relationship between regional trade agreement (RTA) size and trade openness. The authors argue that four of the 11 RTAs they studied have surpassed their optimal size. We conclude with a research note by Lopez, Kundu and Ciravegna, "Born global or born regional? Evidence from an exploratory study in the Costa Rican software industry." The authors find that most software firms in Costa Rica followed a gradual approach to internationalization; those that were early exporters focused on intraregional markets. This provocative piece suggests that the literature on "born globals" misrepresents IB reality; "born regional" may be a more accurate description of international expansion paths.

\section{ACKNOWLEDGEMENTS}

I thank René Belderbos and Alain Verbeke for helpful comments on an earlier draft.
Chen, M.-J., Su, K.-H., \& Tsai, W. 2007. Competitive tension: The awareness-motivation-capability perspective. Academy of Management Journal, 50(1): 101-118. 
Dunning, J. H., \& Lundan, S. M. 2008. Multinational enterprises and the global economy, (2nd ed.). Cheltenham: Edward Elgar. Eden, L., Levitas, E., \& Martinez, R. 1997. The production, transfer and spillover of technology: Comparing large and small multinationals as technology producers. Small Business Economics, 9(1): 53-66.

Harris, R. I. D., \& Robinson, C. 2004. Industrial policy and its effect on total factor productivity in UK manufacturing plants, 1990-1998. Scottish Journal of Political Economy, 51(4): 528-543.
Holcombe, R. G., \& Sobel, R. S. 2001. Public policy toward pecuniary externalities. Public Finance Review, 29(4): 304-325. MacDougall, G. D. A. 1960. The benefits and costs of private investment from abroad: A theoretical approach. Economic Record, 36(73): 13-35.

Pigou, A. C. 1920. The economics of welfare. London: Macmillan Publishing.

Scitovsky, T. 1954. Two concepts of external economies. Journal of Political Economy, 62(2): 143-151. 